\title{
A study of farmer attitudes towards riparian management practices
}

\author{
T.G. PARMINTER, I.S. TARBOTTON and C. KOKICH \\ AgResearch, Ruakura Agricultural Centre, Private Bag 3123, Hamilton
}

\begin{abstract}
Transcripts from a survey of 60 farmers were analysed to identify the attitudes they held towards a range of riparian management practices, and the criteria they would use to select their most preferred practices. Most farmers had mixed attitudes towards managing the riparian area, combining aspects of "pressure farming", and "conservation farming" Pressure farming was considered to result in problems with erosion, sediment, boggy areas, and a lack of stock safety. Conservation farming was considered to be able to provide increased farming income and greater biodiversity. Farmers selected riparian management practices that they thought would reduce the problems caused by pressure farming, and obtain the benefits of conservation farming. But adoption of new technologies would take place only if the technologies were considered to be practical and not to increase management complexity. An understanding of farmers' perceptions about managing riparian areas can help policy agencies target educational interventions encouraging farmers to improve the sustainability of their resource use.
\end{abstract}

Keywords: environment, extension, farmer attitudes, riparian areas, waterway management

\section{Background}

Riparian areas exist alongside all waterways and can be managed inside farm production systems or external to them, by fencing them off or other means of exclusion. The project being reported on was initiated to identify the criteria farmers used to evaluate the suitability of different options for riparian area management (Saaty \& Vargas 1994).

For the purposes of the study, riparian areas were defined as the area alongside waterways such as rivers, streams, and creeks or ditches, and alongside wetlands. Riparian areas were considered to be affected by waterway dynamics (e.g., flooding), and management of riparian areas could itself affect the quality and quantity of nearby water (e.g., through nutrient transfer). In the study if there was any uncertainty about what was to be included within the riparian area it was taken as being land up to 10 metres away from stream banks either side of a water body.

\section{Method}

A total of 60 farmers were surveyed from the King Country and Hawke's Bay electorates. Farmers were randomly selected from a list of people who had listed themselves as "farmers" in the relevant electoral rolls, and who had addresses able to be identified by the researchers. The lists of farmers were than stratified according to region and farm size to improve its representativeness. Any farmers who could not be contacted, or who were not available during the survey period, were replaced by randomly selected farmers meeting the same stratification criteria.

Two survey instruments were used to obtain the required information:

1. Respondents were asked to complete a questionnaire on demographic information in preparation for an interview.

2. An interview with open questions was used to obtain full and personal responses about decision criteria.

In the interview, a semi-structured approach with probe questions was used for riparian management options to ensure the questioner fully understood the answers, and to allow the respondents full expression of their points of view. Although some variation in the questions was allowed for, the questions remained consistent with those contained in an interview guide. Summaries were recorded on audio-tape at the end of each interview.

Survey results and summaries were analysed in separate databases. The survey results were analysed in an EXCEL database using pivot tables. The summaries were analysed using a Non-numerical Unstructured Data

1. Pressure farming was a term applied by some farmers to farming decisions that were likely to result in degradation of natural resources on the more sensitive parts of their properties.

2. Conservation farming was a term applied by some farmers when they put a priority on farming practices that were likely to maintain or enhance the state of their natural resources. 
Indexing Searching and Theorising (NUD.ISTC) computer program, to code and link decision criteria. Coding was developed using a grounded theory approach to sequentially add codes as they were "discovered" in the text. The process was made more rigorous by the three researchers independently coding and interpreting the same material. The decision criteria identified in the summary texts by the researchers was examined further for analogous terms, sub-categories, cluster, and linkages, using NUD.IST.

\section{Results and discussion}

A total of 2640 text units (sentences and part sentences) were transcribed and analysed from the respondents. Many of the farmers surveyed $(60 \%)$ had adopted a riparian management practice (e.g., fencing off a portion of stream bank and planting poplars) along a portion of their riparian area. Most farmers were concerned about the likelihood of their management directly contaminating waterways, but delayed taking action until problems became visible. As a result, farmers did not generally manage their riparian areas differently from the rest of their farmland except in those areas which were considered difficult to farm anyway.

... you exclude cattle from any areas that you can see where they would cause a lot of damage because they can totally destruct the stream banks causing major [erosion] and muddying the waterway.

The only effect your farming could be having on water quality would be silting ...

It was often the women on family farms who expressed strongest concerns about waterway management.

We look after the water, ... we never put anything that is going to do any harm into the water, ... and that's just been a natural thing, like we don't believe in [doing] that sort of thing.

Fencing off riparian areas gave landowners the flexibility to manage those areas differently from the rest of their property. This made fencing one of the most important changes farmers could make to improve riparian management. Even if the area that had been fenced was still intended to be grazed; by managing it separately, grazing could be adapted to suit the unique conditions applying alongside a waterway.

And there are some paddocks ... which you graze lighter so that stock aren't putting pressure on those steep areas beside the waterways.
Fencing could also be used to turn unproductive land into something of value.

Yes, if we had areas that were so wet that it was impractical to do any drainage or anything with them, then we would fence them off and plant native trees around them to be natural.

Once it had been decided to manage riparian areas distinctively from the rest of the farm the financial implications of different farm practices had a strong influence upon the type of management practices being used in the riparian area.

... you feel that if you are going to have the expense of fencing an area off, you may as well get a return on your investment at the end of the day by having some trees out of it or something like that.

A summary of the main criteria used by farmers to evaluate different riparian management options is provided in Table 1. The table has two types of farming outcomes identified from the NUD.IST analysis of the

Table 1 Criteria used by farmers to evaluate riparian management practices.

\begin{tabular}{|c|c|c|}
\hline $\begin{array}{l}\text { Type of } \\
\text { farming }\end{array}$ & Categories of criteria & Criteria \\
\hline \multirow[t]{8}{*}{$\begin{array}{l}\text { Pressure } \\
\text { Farming }\end{array}$} & sediment & $\begin{array}{l}\text { erosion } \\
\text { animal treading }\end{array}$ \\
\hline & contaminated water & $\begin{array}{l}\text { fertiliser } \\
\text { chemicals } \\
\text { animal faeces }\end{array}$ \\
\hline & $\begin{array}{l}\text { increased costs of } \\
\text { management }\end{array}$ & $\begin{array}{l}\text { direct costs } \\
\text { opportunity costs } \\
\text { management complications }\end{array}$ \\
\hline & stock losses & $\begin{array}{l}\text { steep banks } \\
\text { boggy areas }\end{array}$ \\
\hline & land loss & $\begin{array}{l}\text { erosion } \\
\text { flooding }\end{array}$ \\
\hline & mustering problems & $\begin{array}{l}\text { boundaries } \\
\text { grazing } \\
\text { trees }\end{array}$ \\
\hline & animal performance & $\begin{array}{l}\text { poor quality feed } \\
\text { taste (to animals) of water } \\
\text { disease resistance }\end{array}$ \\
\hline & efficient land use & $\begin{array}{l}\text { low financial returns } \\
\text { realising production potential }\end{array}$ \\
\hline \multirow[t]{5}{*}{$\begin{array}{l}\text { Conservation } \\
\text { Farming }\end{array}$} & $\begin{array}{l}\text { intergenerational } \\
\text { transfer }\end{array}$ & $\begin{array}{l}\text { protected nature } \\
\text { regional council involvement }\end{array}$ \\
\hline & greater biodiversity & $\begin{array}{l}\text { pressure habitats } \\
\text { working access } \\
\text { bird life } \\
\text { sport fishes }\end{array}$ \\
\hline & improved aesthetics & $\begin{array}{l}\text { farming } \\
\text { social }\end{array}$ \\
\hline & management easier & $\begin{array}{l}\text { fewer complications } \\
\text { more practical }\end{array}$ \\
\hline & greater income & $\begin{array}{l}\text { optional land uses } \\
\text { useful water resource }\end{array}$ \\
\hline
\end{tabular}


survey. Each type of farming was associated with different categories of criteria used by farmers to discriminate between management practices. Each specific criteria is listed in the criteria column. The criteria are reported in more detail elsewhere (Parminter et al. 1998). The farmers wanted to use riparian management options that would reduce the problems caused by pressure farming and assist them realise the benefits of conservation farming (Shrapnel 1997). Adoption of specific riparian management practices would be enhanced by:

- Increasing the perceived advantages of that practice. This could be done by increasing farmer awareness of all the benefits to water way ecosystems from making the appropriate management changes.

- The disadvantages of using that riparian option being reduced. The costs of riparian management changes can be reduced by making available practical and straightforward (not complex) management advice.

- The negative outcomes from ineffective riparian management being made larger. The long-term costs to farming of ineffective riparian manage-ment can be calculated and promoted to farming communities.

- The advantages of ineffective riparian management being reduced. A more profitable agricultural sector will make the apparent advantages of continuing to use riparian areas for intensive agriculture less important.

The characteristics of management practice options that were given by farmers as reasons for preferring them or rejecting them, are described in Table 2. The most popular management options were planting timber

Table 2 Farmers evaluations of riparian management options.

\begin{tabular}{|c|c|c|c|}
\hline Management option & $\begin{array}{l}\text { Proportion of } \\
\text { farmers for whom } \\
\text { this option was } \\
\text { their highest } \\
\text { preference }\end{array}$ & Main reasons for adoption & Main reasons for not adopting \\
\hline $\begin{array}{l}\text { Planting riparian areas } \\
\text { in timber trees }\end{array}$ & $23 \%$ & $\begin{array}{l}\text { "getting better income off that land, and also } \\
\text { you can graze it..." } \\
\text { "stabilise erosion" } \\
\text { "provide shelter" } \\
\text { "aesthetic value - tidies up the area" } \\
\text { "spreading income sources" } \\
\text { "control weeds without hard labour" }\end{array}$ & $\begin{array}{l}\text { "labour required to tend timber trees" } \\
\text { "paying someone to prune then" } \\
\text { "shading the pasture with trees" } \\
\text { "hard to establish" } \\
\text { "trees falling into the river..." } \\
\text { "having to protect the trees..." }\end{array}$ \\
\hline $\begin{array}{l}\text { Planting riparian areas } \\
\text { in conservation trees }\end{array}$ & $21 \%$ & $\begin{array}{l}\text { "stops stream banks collapsing" } \\
\text { "conservation trees hold land together, } \\
\text { provide shade, shelter, some feed... } \\
\text { bring birdlife, beautify property" } \\
\text { "control weeds without extra labour" }\end{array}$ & $\begin{array}{l}\text { "no economic benefit from conservation trees" } \\
\text { "possums have more shelter (rabbits also)" } \\
\text { "more problems with stock mustering" }\end{array}$ \\
\hline $\begin{array}{l}\text { Excluding all pesticides } \\
\text { from a } 10 \text { metre } \\
\text { riparian area }\end{array}$ & $16 \%$ & $\begin{array}{l}\text { "pesticides don't like me, and I don't like } \\
\text { them" } \\
\text { "not putting poison into the farm" }\end{array}$ & $\begin{array}{l}\text { "excluding pesticides allows noxious weeds to } \\
\text { overrun that area" } \\
\text { "get overrun by noxious weeds" }\end{array}$ \\
\hline $\begin{array}{l}\text { Using only formed } \\
\text { tracks with bridges and } \\
\text { culverts, when moving } \\
\text { animals across } \\
\text { waterways }\end{array}$ & $16 \%$ & $\begin{array}{l}\text { "keeping stock clean and dry" } \\
\text { "convenience for stock and motorbike } \\
\text { movement" } \\
\text { "less vulnerable to restricted access during } \\
\text { floods" }\end{array}$ & "cost" \\
\hline $\begin{array}{l}\text { Excluding cattle, in } \\
\text { selected seasons } \\
\text { (e.g., winter) from } \\
\text { riparian areas }\end{array}$ & $14 \%$ & $\begin{array}{l}\text { "so cattle wont make a mess in winter" } \\
\text { "use electric fencing so can graze all available } \\
\text { land if possible..." } \\
\text { "to exclude stock from water all year round } \\
\text { would be silly as the quality is too good" } \\
\text { "exclude cattle in winter because of the } \\
\text { damage they re likely to do to creek } \\
\text { banks" }\end{array}$ & "reduce pasture quality if no cattle are there" \\
\hline $\begin{array}{l}\text { Excluding all livestock } \\
\text { grazing from riparian } \\
\text { areas, but no } \\
\text { deliberate planting }\end{array}$ & $7 \%$ & $\begin{array}{l}\text { "avoids waterway bank damage" } \\
\text { "avoids blocking up all the creeks" }\end{array}$ & $\begin{array}{l}\text { "less grazed area" } \\
\text { "loss of income" } \\
\text { "stock getting stuck in the creek" } \\
\text { "farm access becoming more difficult" } \\
\text { "extra costs..." } \\
\text { "physical difficulties - fencing and defining } \\
\quad \text { where to start and stop" }\end{array}$ \\
\hline $\begin{array}{l}\text { Excluding all fertiliser } \\
\text { material (chemical or } \\
\text { organic) from } 10 \text { meter } \\
\text { riparian area }\end{array}$ & $4 \%$ & $\begin{array}{l}\text { "no monetary gain from fertilising those areas" } \\
\text { "easiest to implement" }\end{array}$ & $\begin{array}{l}\text { "up to the truck driver" } \\
\text { "driver would probably stay too far away and } \\
\text { miss a strip of the paddock" }\end{array}$ \\
\hline $\begin{array}{l}\text { Preserving or re-estab- } \\
\text { lishing wetlands along } \\
\text { waterways. May } \\
\text { include "undraining" }\end{array}$ & $0 \%$ & & $\begin{array}{l}\text { "likely to be too slow to get a good wetland } \\
\text { established" }\end{array}$ \\
\hline
\end{tabular}


trees or conservation trees in riparian areas. The least popular options were preserving wetlands or excluding fertiliser. The main motivating benefits of riparian management change were visible benefits to water quality.

The main limitations to making changes were farmers' perceptions that they would decrease farm production or add costs. Likely perceived benefits could be predicted from the functional attributes of the options, but their limitations could only be determined by knowing the interactions between each of the options and the types of farming systems in which they would be used.

\section{Conclusions}

- Pressure farming concepts could be considered as negative outcomes from management practices which may be suitable on some parts of farms, but are unsuitable alongside water ways. Conservation farming concepts are the positive outcomes from effectively managing riparian areas.

- Agencies that want to change the riparian management of farmers should simultaneously promote both the problems of pressure farming and the benefits of conservation farming. This can be done by providing information to farmers with advice that is practical, straightforward, and comprehensive enough to cover both resource management issues, and the financial effects of change.

- A more profitable agricultural sector will encourage farmers to be more flexible in their land use options for marginal farm land along waterways.

- On livestock farms, fencing of riparian areas was the most important management change, as it enabled farmers to manage the area more appropriately whether or not it remained in grazing.
- Planting trees for timber or conservation were the most preferred land use options for riparian areas. Farmers' experiences with planted areas should be documented in a further study and provided to other farmers for their learning.

- Protecting wetlands was the least preferred management option. Further research should be carried out into the value of wetlands on farms so that land owners can make their own assessments and establish their priority.

\section{ACKNOWLEDGEMENTS}

The authors greatly appreciated the farmers that made their time available for the survey interviews. Also the work carried out by Lyn Hanes, Jenny Moore, and Justine Pederson on the NUD.IST analysis.

The project was funded by the Foundation of Science, Research and Technology.

\section{REFERENCES}

Parminter, T.G.; Tarbotton, I.S.; Kokich C. 1998. AgResearch Report on the Hill Land Catchment Study of Riparian Margins: Decision Criteria Survey Summary. Internal AgResearch report, March 1998.

Saaty, T.L.; Vargas, L.G. 1994. Decision making in economic, political, social and technological environments: the analytical hierarchy process Vol VII. Pittsburgh: RWS Publications.

Shrapnel, M.; Davie, J.; Frank, B. 1997. Influence of psychological factors on policies and options for ecologically sustainable land management. Proceedings of the $2^{\text {nd }}$ Australiasia Pacific Extension Conference: Managing Change - Building Knowledge and Skills. Vol II: 236-244. 